\title{
Post-fire reproduction of herbs at a savanna-gallery forest boundary in Distrito Federal, Brazil
}

\author{
K. G. Massia*, C. U. O. Eugênio ${ }^{b}$ and A. C. Franco ${ }^{c}$

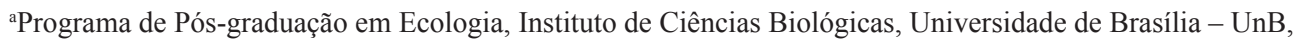 \\ Campus Darcy Ribeiro, CEP 70910-900, Brasília, DF, Brazil \\ bPrograma de Pós-graduação em Botânica, Instituto de Ciências Biológicas, Universidade de Brasília - UnB, \\ Campus Darcy Ribeiro, CEP 70910-900, Brasília, DF, Brazil \\ 'Departamento de Botânica, Instituto de Ciências Biológicas, Universidade de Brasília - UnB, Campus Darcy Ribeiro, \\ CP 04457, CEP 70919-970, Brasília, DF, Brazil \\ *e-mail:kgmassi@gmail.com
}

Received: May 3, 2016 - Accepted: July 21, 2016 - Distributed: November 31, 2017

(With 1 figure)

\begin{abstract}
In Cerrado, studies of post-fire vegetation recovery show that some herbaceous species are able to flower shortly after fires. However, these were mainly short-term studies that focused on grasslands and savannas. Little is known about the effects of fire on ground layer of forests that border the savannas in Central Brazil. Thus, an accidental burning gave us the opportunity to describe the reproductive activity of the ground layer vegetation after a fire event along a savanna-forest boundary at the IBGE Ecological Reserve, Brasília, Brazil. During the 16-month of the inventory, we registered 170 herbaceous species flowering or fruiting, of which 52 species (31\%) may have been influenced by fire that changed their times of reproduction. In the savanna plots reproduction peaked at the end of the rainy season. Of the total number of reproducing species, 90 species occurred only in the savanna and four in the forest. Five herbs were recorded in the forest, savanna and border environments. Late dry season fire probably lead the majority of herbaceous species to have their reproduction spread throughout the study time.
\end{abstract}

Keywords: savanna-forest boundary, reproductive phenology, fire-effect, Cerrado.

\section{Reprodução pós-fogo de espécies do estrato herbáceo em área de transição Cerrado-Mata de Galeria no Distrito Federal, Brasil}

\section{Resumo}

No Cerrado, estudos de recuperação da vegetação pós-fogo mostram que algumas espécies herbáceas são capazes de florescer logo após queimadas. No entanto, esses foram principalmente estudos de curto prazo, que se concentraram em áreas campestres e savânicas. Pouco se sabe sobre os efeitos do fogo no sub-bosque de matas que margeiam as savanas do Brasil Central. Assim, uma queima acidental nos deu a oportunidade de descrever a atividade reprodutiva pós-fogo do estrato herbáceo ao longo de ecótono cerrado-mata na Reserva Ecológica do IBGE, Brasília, Brasil. Durante os 16 meses do inventário, foram registrados 170 espécies herbáceas com flores ou frutos, das quais 52 espécies (31\%) podem ter sido influenciadas pelo fogo, que alterou suas épocas reprodutivas. Nas parcelas de cerrado, a reprodução teve seu pico ao final da estação chuvosa. Do número total de espécies, 90 ocorreram exclusivamente no cerrado e quatro na floresta. Cinco espécies herbáceas foram registradas na floresta, cerrado e borda. O fogo ao final da estação seca pode ter levado a maioria das plantas a se reproduzir através do período de estudo.

Palavras-chave: ecótono cerrado-mata, fenologia reprodutiva, efeito do fogo, Cerrado.

\section{Introduction}

Fire has been occurring in the Brazilian savannas (Cerrado) for 10 million years and is associated with physiognomies where grasses and herbs are present (Simon et al., 2009; Simon and Pennington, 2012). Cerrados usually border more closed vegetation types, as forests, and if a burning happens, fire will affect plants from both cerrado and forest. However, tree species of gallery forests are less tolerant to fire than savanna species (Hoffmann et al., 2012), and although little is known about what happens with the forest understory after a burning event, we could expect a fire-sensitive forest understory when compared to a fire-adapted cerrado ground-layer. 
In the absence of fire, most herbs tend to grow and reproduce during the wet season (Sarmiento, 1984; Batalha and Martins, 2004). Thus, a fire that occurs in the dry season would remove the dry biomass (Ramos-Neto and Pivello, 2000) and stimulate a fast recovery of the non-woody species after the first rains (Gottsberger and Silberbauer-Gottsberger, 2006; Munhoz and Amaral, 2010). The effects of burning on reproduction may be more complex though. Some studies conducted in Cerrado areas have shown that herbaceous species are able to flower and fruit shortly after fires (Coutinho, 1976; César, 1980; Munhoz and Felfili, 2007); while in a grassland in the South of Brazil, Fidelis and Blanco (2014) showed some species only reproducing more than one year after fire.

In addition to the complexity of this issue, most researchers have conducted only a few months of observations after fire and almost none of them have evaluated the post-fire phenology patterns of a cerrado sensu stricto-gallery forest ecotone. So, we aimed to describe the reproductive activity (flowering + fruiting) of the ground layer vegetation after a fire event along a savanna-forest boundary during 16 months after an accidental fire.

\section{Material and Methods}

\subsection{Site description}

The study was performed at the IBGE (Instituto Brasileiro de Geografia e Estatística) Ecological Reserve, located $35 \mathrm{~km}$ south of Brasilia, in the Federal District of Brazil $\left(15^{\circ} 55^{\prime}-15^{\circ} 58^{\prime} \mathrm{S}\right.$ and $\left.47^{\circ} 52^{\prime}-47^{\circ} 55^{\prime} \mathrm{W}\right)$, at an elevation of $1,100 \mathrm{~m}$. The Reserve encloses different Cerrado vegetation physiognomies, such as grasslands, savanna (cerrado sensu stricto), woodlands and gallery forests (Ribeiro, 2011). The average annual rainfall recorded at IBGE meteorological station is 1,461 mm (1980-2008), with a well-defined dry season from May to September and a mean annual temperature of $22.5^{\circ} \mathrm{C}$ (Paiva et al., 2015). At the time this study was performed (2011-2013) yearly rainfall was $1,418 \mathrm{~mm}$; driest months were from June to August, when burnings can happen (RECOR, 2013). Soils at the reserve are deep well-drained oxisols (Ribeiro, 2011).

\subsection{Sampling design}

The research was carried out at the boundary between gallery forest and savanna. Six transects were positioned perpendicularly to the boundary; each transect was $10 \mathrm{~m} \times 70 \mathrm{~m}$ and extended $30 \mathrm{~m}$ into the savanna, $10 \mathrm{~m}$ into the border and $30 \mathrm{~m}$ into the forest. An accidental fire occurred in September 2011 and burned savanna and forest environments, which had only burned once in the previous 35 years due to a policy of fire suppression in the reserve (Ribeiro, 2011). This accident gave us the chance to observe post-fire flowering and fruiting of herbs. We did not have data from non-burned areas, but we checked dates of collected fertile material of the studied species from SpeciesLink website to make comparison possible (SpeciesLink, 2016).
During the 16 month post-fire survey, we registered ground layer species with flowers and/or fruits in all transects, as the majority of herbs species had rapid flowering and fruiting, that overlapped in time. In the first four months, survey was fortnightly (seven surveys total) because of the quick post-fire response of herbs (Coutinho, 1976). After this period and until January 2013 the surveys were done seasonally (in the beginning, middle and end of each season), which added up to six surveys. Fertile material was herborized, identified and deposited at Herbário da Universidade de Brasília. For plant family classification, we used the Angiosperm Phylogeny Group III (APG III, 2009). Ground layer plants, e.g, grasses, herbs, vines and subshrubs shorter than $1.5 \mathrm{~m}$ were considered herb species (Rizzini, 1997).

To test whether cerrado, border and gallery-forest herbaceous species reproduced uniformly through the first year post-fire (from October 2011 to October 2012), we applied Rayleigh test (Zar, 1999). Statistical analyses were performed using the R version 3.2.1 (R Development Core Team, 2013).

\section{Results}

We registered 170 herb species flowering or fruiting during the study time, distributed in 37 families. The most abundant families were Asteraceae, Fabaceae and Poaceae (each with 22, 22 and 21 species, respectively), followed by Cyperaceae, Euphorbiaceae, Malphigiaceae, Myrtaceae and Rubiaceae (with eight species each), which altogether represented $62 \%$ of the richness. Three species were exotic/invasive (Ageratum fastigiatum, Melinis minutiflora and Sida linifolia). We found 158 species in savanna (90 species were exclusive of this environment) and 17 species in the gallery forest (only four species exclusive to this vegetation). Five species were common among the gallery forest, cerrado and border (Bauhinia rufa, Cyperaceae sp.1, Croton antisyphiliticus, Melinis minutiflora, Psychotria cf. nemorosa; Table 1).

In savanna, herb reproduction peaked seven months after the fire event (57 species flowering and or fruiting at the end of the rainy season $(r=0.1135, p=0.004$; Figure 1$)$. In the border, peak was in January, two months earlier than in cerrado ( $r=0.2567, p<0.0001$; Figure 1$)$. Gallery forest had no seasonality in understory post-fire flowering and fruiting ( $\mathrm{r}=-0.1997, \mathrm{p}=0.9065$; Figure 1).

We registered 38 species that reproduced only in the first four months after fire and that did not present reproductive structures during the rest of the survey (marked with a star sign in Table 1, these species occurred mainly in savanna). We also registered 16 species that had a different post-fire reproductive period when compared with commonly registered phenological data (marked with a plus sign in Table 1). Two species (Barjonia cymosa and Busbostylis pachypoda) had a single reproduction episode in the first four months after fire and at a different time from the normal pattern registered for both species. 


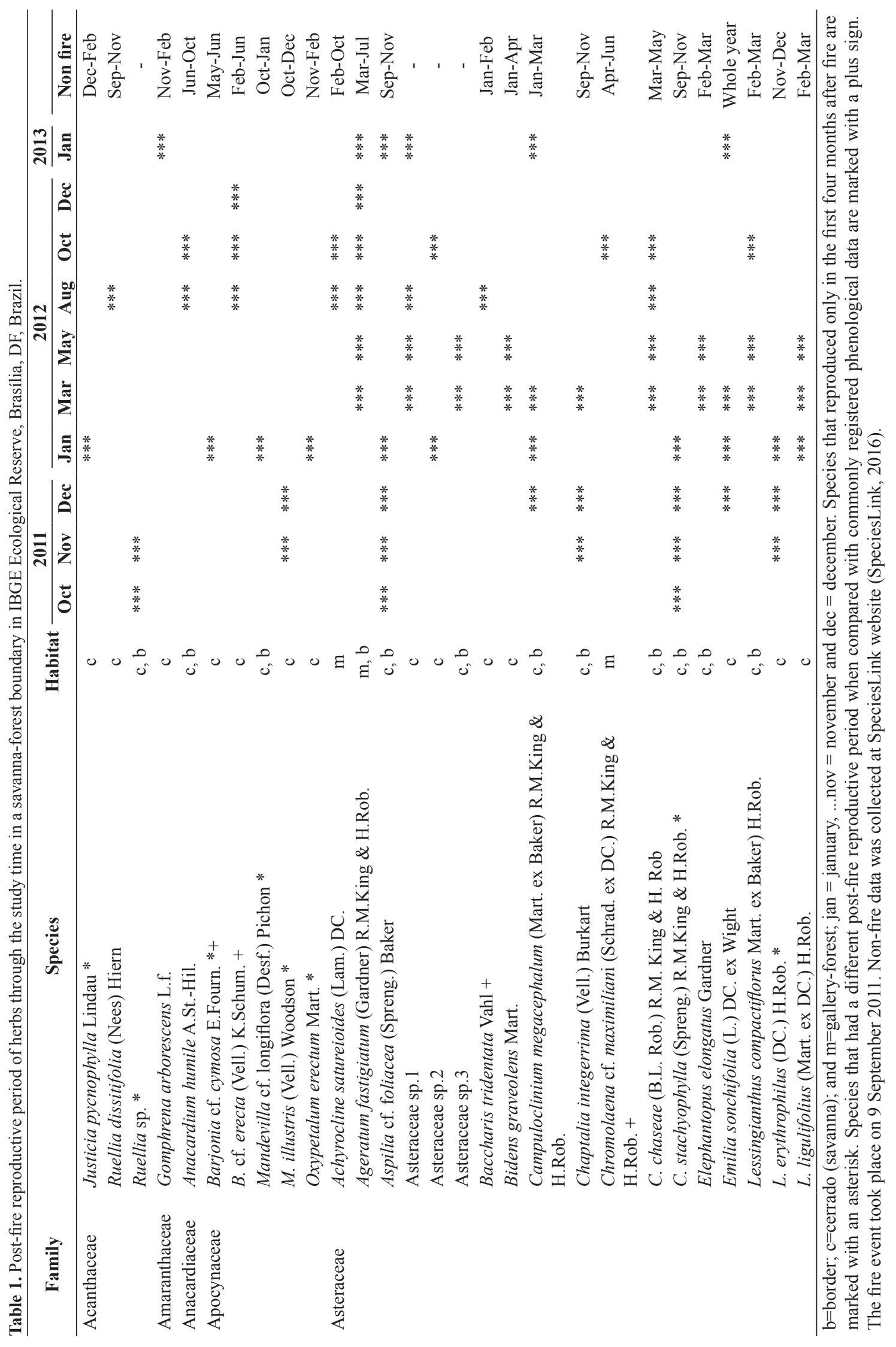




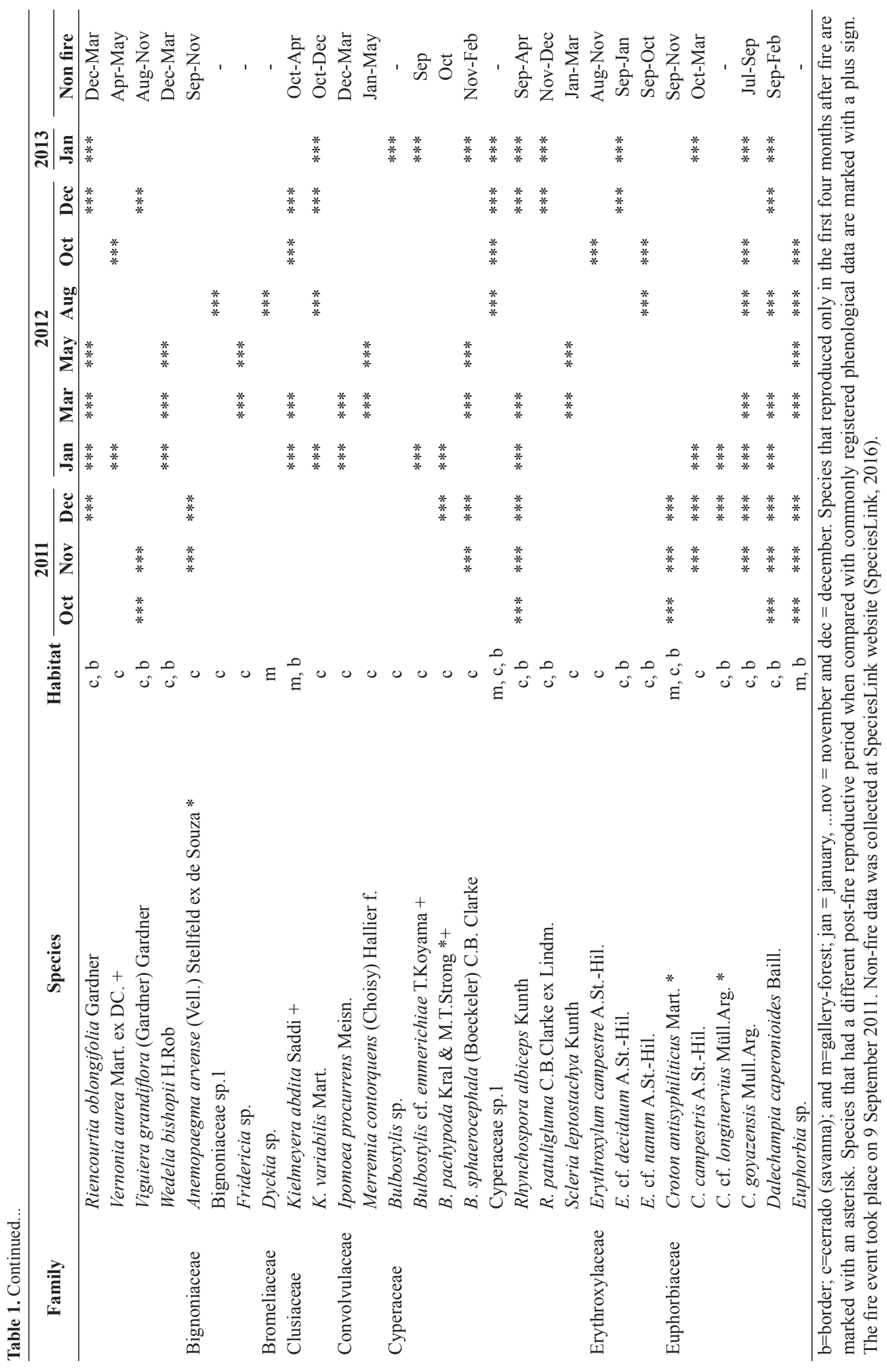




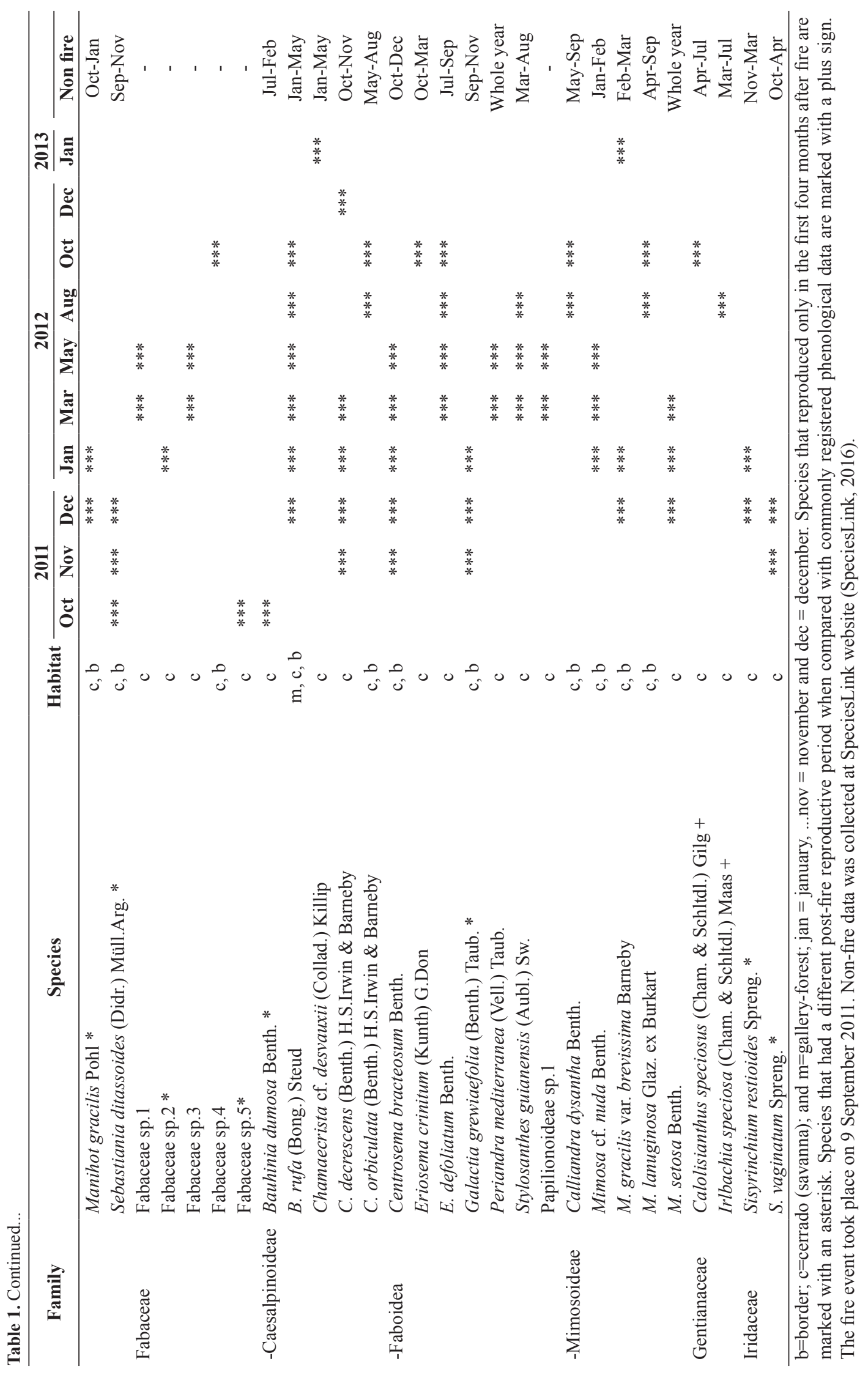




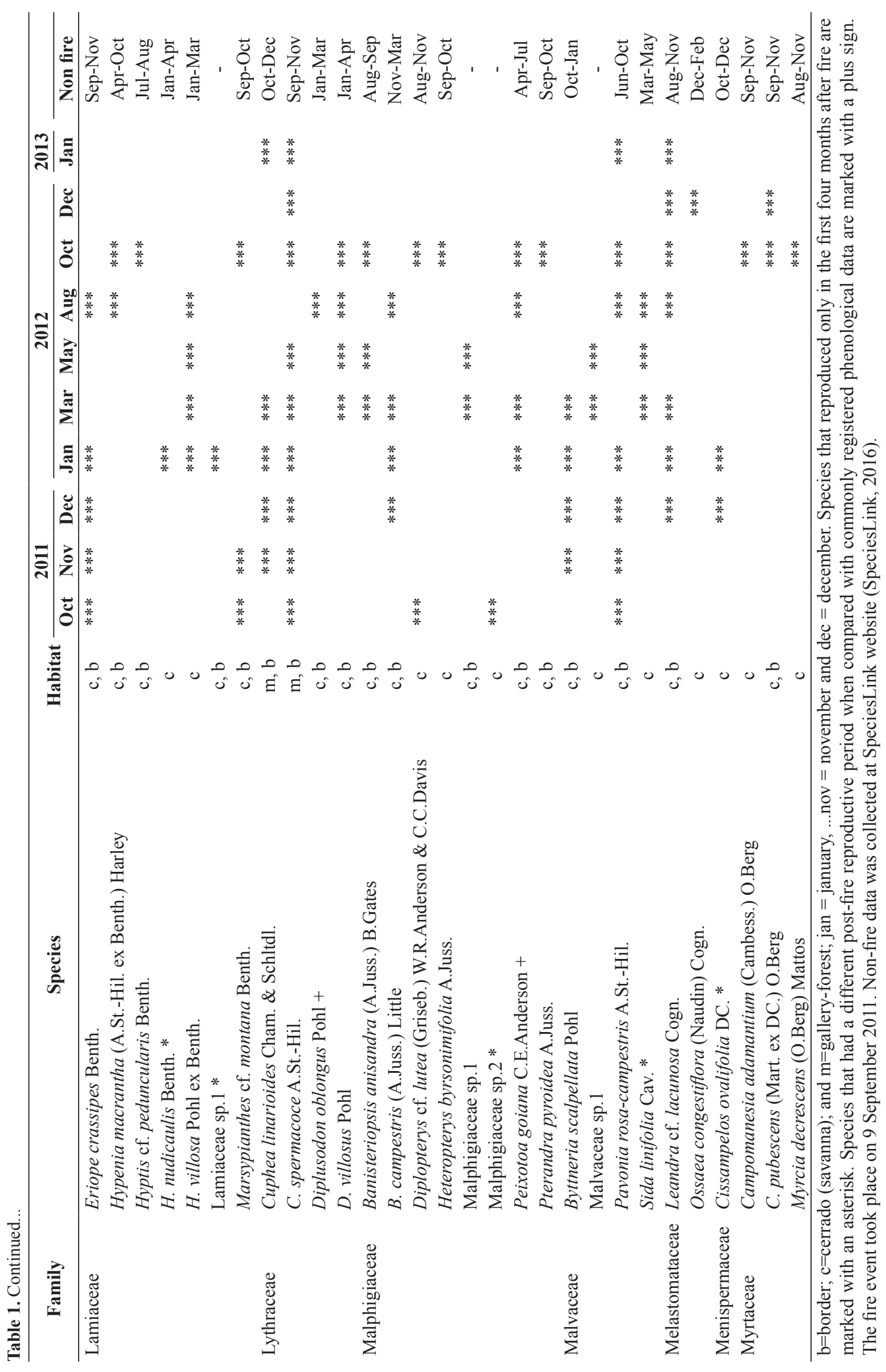




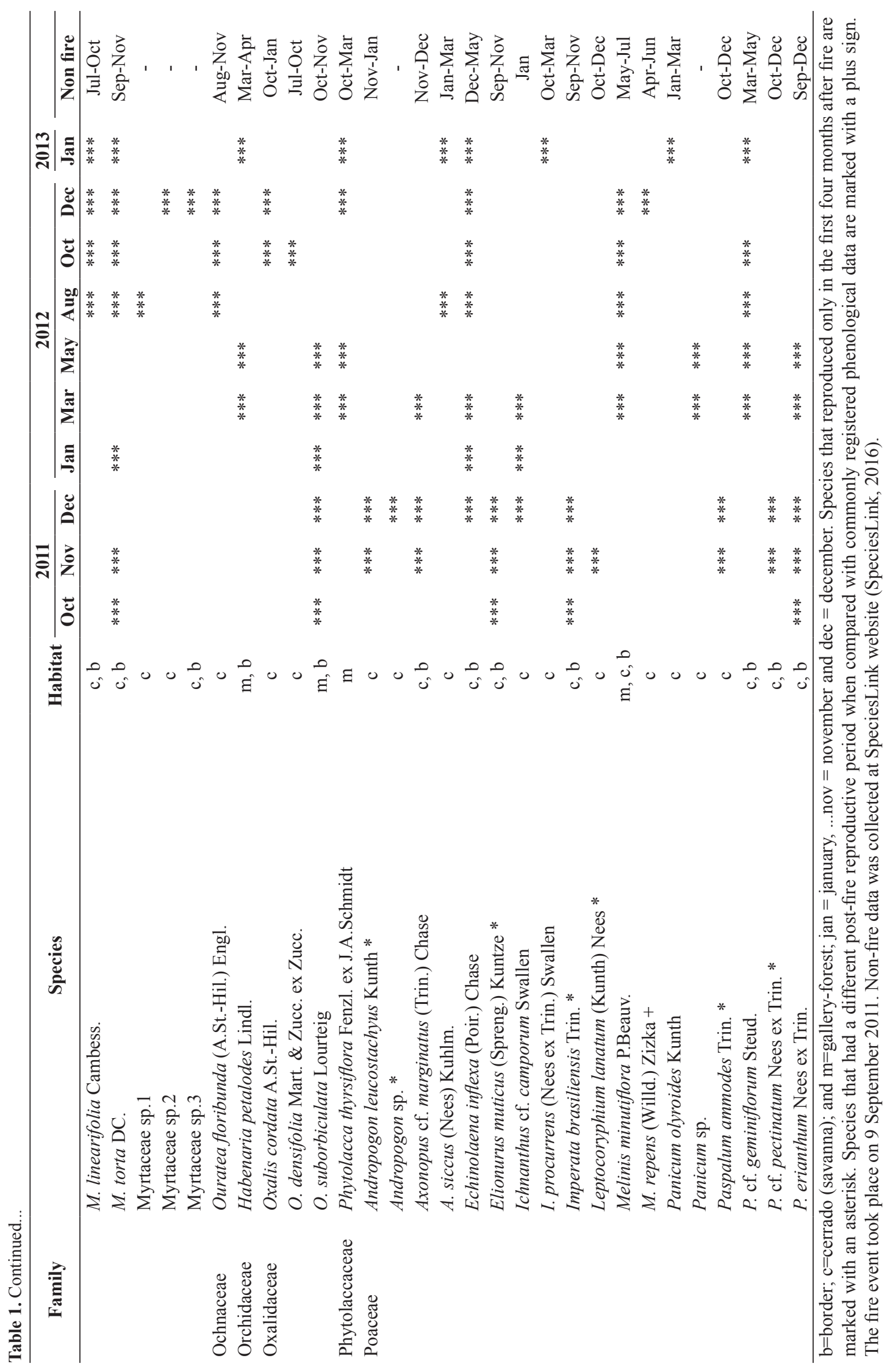




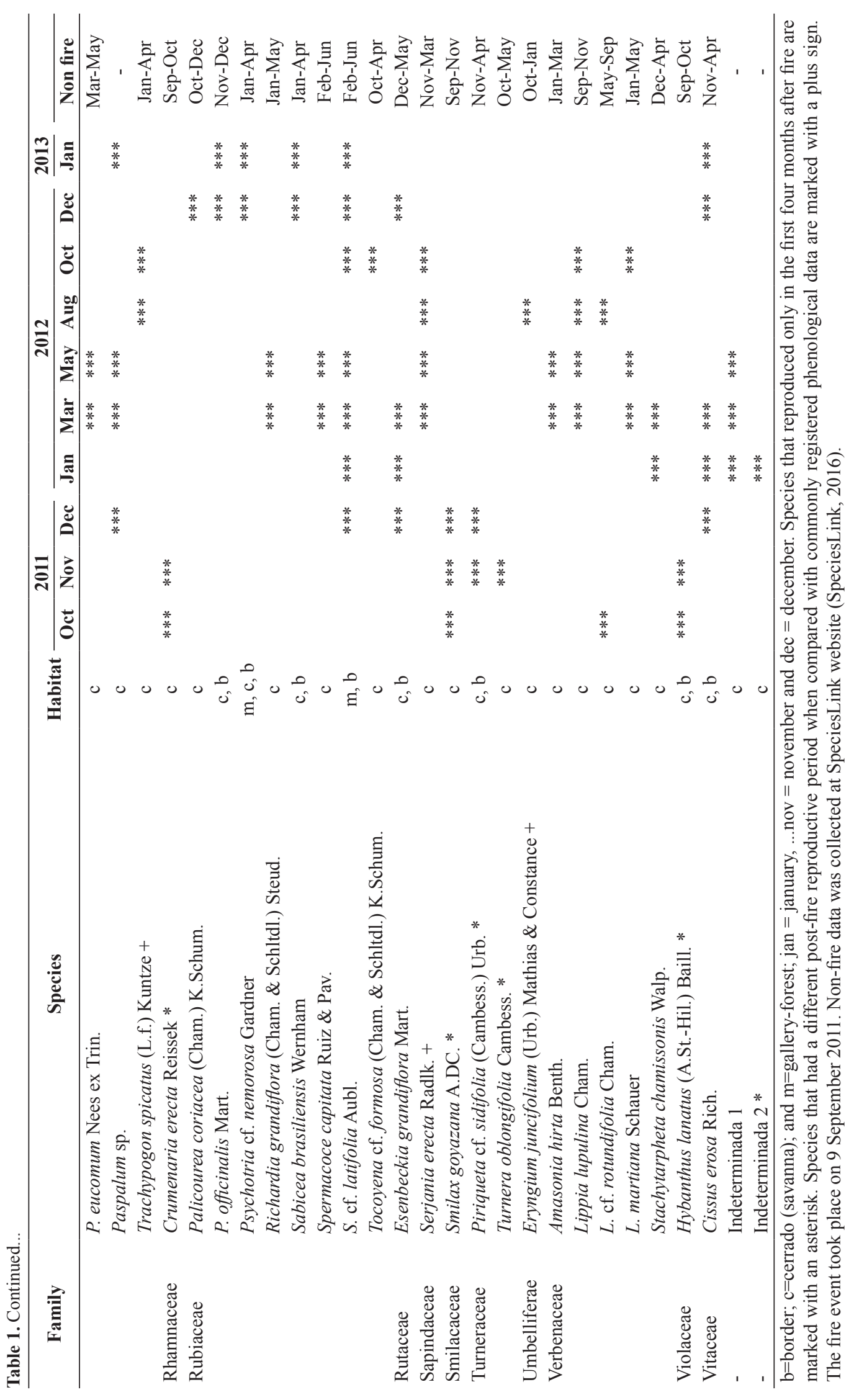




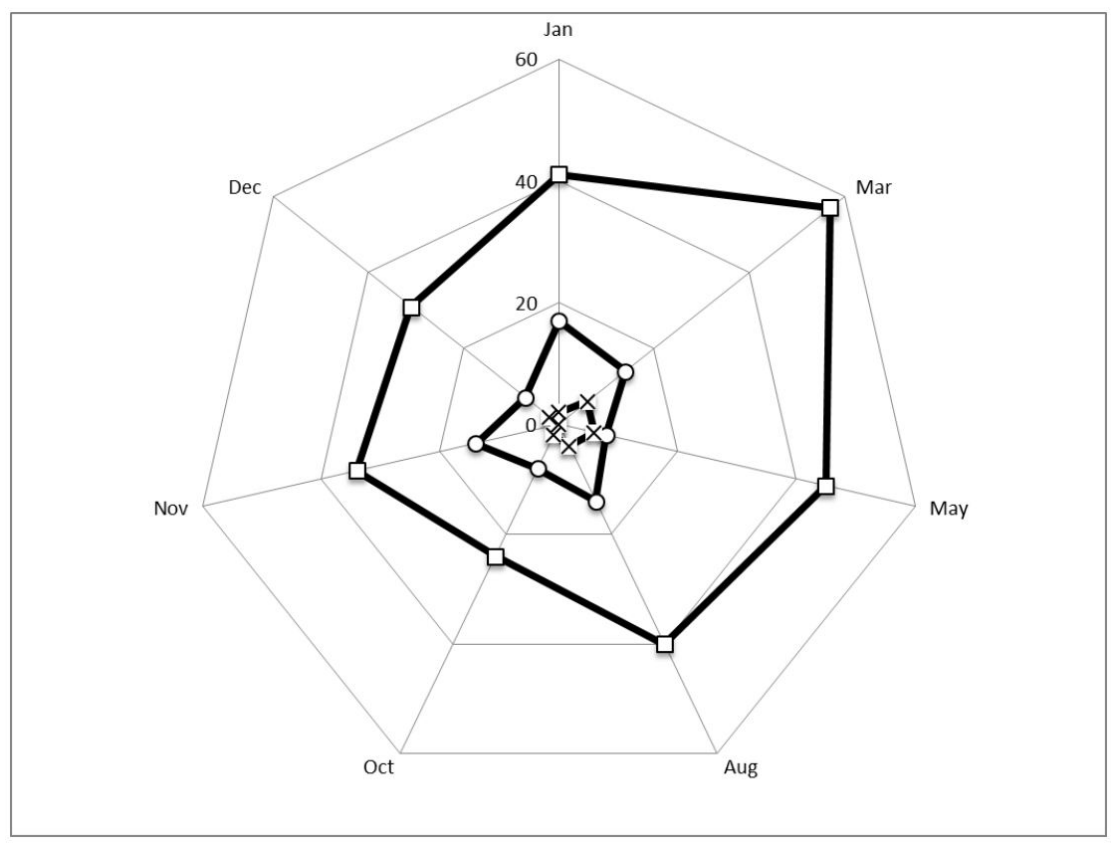

Figure 1. Number of herbs that reproduced through the first year after fire, in a savanna-forest boundary ( $\square$ represents species that occurred in cerrado vegetation; $\bigcirc$, in the border; and $\times$, in forest), in IBGE Ecological Reserve, Brasília, DF, Brazil. The fire event took place on 9 September 2011 and thus, October is the first post-fire inventory.

\section{Discussion}

Among the species that flowered or fruited in the 16-month study, the most abundant families sampled were Asteraceae, Fabaceae and Poaceae. The same result was found in flora surveys realized in post-fire grassland areas in Distrito Federal (Munhoz and Amaral, 2010) and Mato Grosso do Sul (Neves and Damasceno-Júnior, 2011). In fact, such families are dominant in the non-woody flora of Cerrado (Mendonça et al., 1998; Filgueiras, 2002) and locally, in savanna and grassland areas in the IBGE Reserve protected from fire (Pereira and Silva, 2011).

Reproduction of cerrado species peaked about seven months after fire, at the end of the rainy season, which is expected in a seasonal vegetation, such as Cerrado (Batalha and Martins, 2004). The change in the observation interval of the reproductive events (from fortnightly to bimonthly) might have subsampled the community phenological patterns, but our results agree with Munhoz and Felfili (2007) and Tannus et al. (2006), which indicated a peak of flowering for the herbaceous community at the end of rainy season. In the border, the number of species with flowers and/or fruits was greater in the middle of the rainy season, therefore earlier than in savanna, that had its reproductive peak in the end of the rainy season. Although 63 species were common to both environments, species that started reproducing from March were exclusive of cerrado (Table 1).

It is well known that shading of ground-layer in riparian forests limits plant richness (Felfili et al., 2001), as we observed for the studied area (where only 17 species were registered in the forest when compared to the 158 species of cerrado). Fires in gallery forest generally cause extensive topkill to small trees (Hoffmann et al., 2009) and leaf-fall to larger diameter trees (personal observation), allowing increased light to the forest floor. Thus, we might expect that this higher light availability would stimulate understory species to reproduce. On the contrary, we noticed a fire-sensitive reproduction of the gallery-forest understory.

We registered 52 species (31\%) that may have been influenced by fire changing their times of reproduction. Several factors can trigger flowering after fire, such as increase in light (Brewer, 1995), temperature and soil nutrients (Elzinga et al., 2007). However, Coutinho (1982) argues that the induction of cerrado plant species flowering by fire is not a result of thermal effects during burning or of mineral nutrients supplied by the ashes, but what seems important is the removal of old branches and possible flowering inhibitors. The same has been shown by Fidelis and Blanco (2014), for subtropical grasslands. Therefore, the occurrence of a reproductive cycle soon after fire could result in a more efficient reproductive strategy for this plant guild, because the elimination of the herbaceous/grass layer provides greater visibility of the flowers to pollinators and because flowering synchrony between individuals favors crossings, especially for smaller species (Trabaud and Chanterac, 1985).

In summary, we have found a peak in reproduction seven months after fire for the cerrado and a small number of ground-layer species in the forest. We verified some 
cerrado species that may have been favored by the late dry season fire, but the majority of herbs had their reproduction events spread throughout the study time. The fire timing is able to change the flowering phenology of a grassland community (Rissi, 2016) and this changing may be related to the plant physiological status when burning happens (Frost and Robertson, 1987). In Cerrado, fire is an integral component of the biodiversity (Simon et al., 2009) and a fire management policy with prescribed and well-controlled fires at the correct frequency and season (Durigan and Ratter, 2016) would benefit the reproductive activity of some herbaceous species.

\section{Acknowledgements}

We thank to CNPq (process number 140663/2012-6) and CAPES (process number 17583/12-8) for funding and to the IBGE Ecological Reserve for permission to conduct research. We also thank to an anonymous reviewer for useful suggestions.

\section{References}

APG III, 2009. An update of the Angiosperm Phylogeny Group classification for the orders and families of flowering plants. Botanical Journal of the Linnean Society, vol. 161, no. 2, pp. 105-121. http://dx.doi.org/10.1111/j.1095-8339.2009.00996.x.

BATALHA, M.A. and MARTINS, F.R., 2004. Reproductive phenology of the cerrado plant community in Emas National Park (central Brazil). Australian Journal of Botany, vol. 52, no. 2, pp. 149-161. http://dx.doi.org/10.1071/BT03098.

BREWER, J.S., 1995. The relationship between soil fertility and fire-stimulated floral induction in two populations of grass-leaved golden aster, I. Oikos, vol. 74, no. 1, pp. 45-54. http://dx.doi. org/10.2307/3545673.

CÉSAR, H.L., 1980. Efeitos da queima e corte sobre a vegetação de campo sujo na Fazenda Água Limpa, Brasilia-DF. Brasília: Universidade de Brasília, 59 p. Masters Dissertation.

COUTINHO, L.M., 1976. Contribuição ao conhecimento do papel ecológico das queimadas na floração de espécies do Cerrado. São Paulo: Universidade de São Paulo, 173 p. PhD Thesis.

COUTINHO, L.M., 1982. Ecological effects of fire in Brazilian cerrado. In: B.J. HUNTLEY and B.H. WALKER, eds. Ecology of tropical savanas. Berlin: Springer-Verlag, pp. 273-291.

DURIGAN, G. and RATTER, J.A., 2016. The need for a consistent fire policy for Cerrado conservation. Journal of Applied Ecology, vol. 53, no. 1, pp. 11-15. http://dx.doi.org/10.1111/1365-2664.12559.

ELZINGA, J.A., ATLAN, A., BIERE, A., GIGORD, L., WEIS, A.E. and BERNASCONI, G., 2007. Time after time: flowering phenology and biotic interactions. Trends in Ecology \& Evolution, vol. 22, no. 8, pp. 432-439. PMid:17573151. http://dx.doi. org/10.1016/j.tree.2007.05.006.

FELFILI, J.M., FRANCO, A.C., FAGG, C.W. and SOUSASILVA, J.C., 2001. Desenvolvimento inicial de espécies de Mata de Galeira. In: J.F. RIBEIRO, C.E.L. FONSECA and J.C. SOUSA-SILVA, eds. Cerrado: caracterização e recuperação de Matas de Galeria. Planaltina: Embrapa Cerrados, pp. 779-811.
FIDELIS, A. and BLANCO, C., 2014. Does fire induce flowering in Brazilian subtropical grasslands? Applied Vegetation Science, vol. 17, no. 4, pp. 690-699. http://dx.doi.org/10.1111/avsc.12098.

FILGUEIRAS, T.S., 2002. Herbaceous plant communities. In: P.S. OLIVEIRA and J.R. MARQUIS, eds. The cerrados of Brazil: ecology and natural history of a neotropical savanna. New York: Columbia University Press, pp. 121-139.

FROST, P.G.H. and ROBERTSON, F., 1987. The ecological effects off ire in savannas. In: B.H. WALKER, ed. Determinants of tropical savanas. Oxford: IRL Press, pp. 93-140. IUBS Monograph Series, no. 3.

GOTTSBERGER, G. and SILBERBAUER-GOTTSBERGER, I., 2006. Life in the Cerrado: a South American Tropical seasonal vegetation: pollination and seed dispersal. Ulm: Reta Verlag. 277 p. vol. 2 .

HOFFMANN, W.A., ADASME, R., HARIDASAN, M., CARVALHO, M., GEIGER, E.L., PEREIRA, M.A.B., GOTSCH, S.G. and FRANCO, A.C., 2009. Tree topkill, not mortality, governs the dynamics of alternate stable states at savanna-forest boundaries under frequent fire in central Brazil. Ecology, vol. 90, no. 5, pp. 1326-1337. PMid:19537552. http://dx.doi.org/10.1890/08-0741.1.

HOFFMANN, W.A., GEIGER, E.L., GOTSCH, S.G., ROSSATTO, D.R., SILVA, L.C.R., LAU, O.L., HARIDASAN, M. and FRANCO, A.C., 2012. Ecological thresholds at the savannaforest boundary: how plant traits, resources and fire govern the distribution of tropical biomes. Ecology Letters, vol. 15, no. 7, pp. 759-768. PMid:22554474. http://dx.doi.org/10.1111/j.14610248.2012.01789.x.

MENDONÇA, R.C., FELFILI, J.M., WALTER, B.M.T., JÚNIOR, M.C.S., REZENDE, A.V., FILGUEIRAS, T.S. and NOGUEIRA, P.E., 1998. Flora vascular do cerrado. In: S.M. SANO and S.P. ALMEIDA, eds. Cerrado: ambiente e flora. Planaltina: Embrapa, pp. 289-556.

MUNHOZ, C.B.R. and AMARAL, A.G.,2010. Efeito do fogo no estrato herbáceo-subarbustivo. In: H.S. MIRANDA, ed. Efeitos do regime de fogo sobre a estrutura de comunidades de cerrado: projeto de fogo. Brasília: Ibama, pp. 93-102.

MUNHOZ, C.B.R. and FELFILI, J.M., 2007. Reproductive phenology of an herbaceous-subshrub layer of a Savannah (Campo Sujo) in the Cerrado Biosphere Reserve I, Brazil. Brazilian Journal of Biology $=$ Revista Brasileira de Biologia, vol. 67, no. 2, pp. 299-307. PMid:17876440. http://dx.doi.org/10.1590/ S1519-69842007000200015.

NEVES, D.R.M. and DAMASCENO-JUNIOR, G.A., 2011. Post-fire phenology in a campo sujo vegetation in the Urucum plateau, Mato Grosso do Sul, Brazil. Brazilian Journal of Biology = Revista Brasileira de Biologia, vol. 71, no. 4, pp. 881-888. http://dx.doi.org/10.1590/S1519-69842011000500009.

PAIVA, A.O., SILVA, L.C.R. and HARIDASAN, M., 2015. Productivity-efficiency tradeoffs in tropical gallery forest-savanna transitions: linking plant and soil processes through litter input and composition. Plant Ecology, vol. 216, no. 6, pp. 775-787. http://dx.doi.org/10.1007/s11258-015-0466-8.

PEREIRA, B.A.S. and SILVA, M.A., 2011. Flora arbustivo-herbácea e gramíneas da Reserva Ecológica do IBGE. In: M.L. RIBEIRO, ed. Reserva Ecológica do IBGE. Rio de Janeiro: Coordenação de Recursos Naturais e Estudos Ambientais, pp. 64-73.

R DEVELOPMENT CORE TEAM, 2013 [viewed 14 March 2013]. $R$ : a language and environment for statistical computing 
[online]. Vienna: R Foundation for Statistical Computing. Available from: http://www.R-project.org

RAMOS-NETO, M.B. and PIVELLO, V.R., 2000. Lightning fires in a Brazilian savanna national park: re-thinking management strategies. Environmental Management, vol. 26, no. 6, pp. 675684. PMid:11029117. http://dx.doi.org/10.1007/s002670010124.

RESERVA ECOLÓGICA DO IBGE - RECOR, 2013 [viewed 14 March 2013]. Dados meteorológicos [online]. Available from: http://www.recor.org.br/

RIBEIRO, M.L.,2011. Reserva Ecológica do IBGE: biodiversidade terrestre. Rio de Janeiro: Coordenação de Recursos Naturais e Estudos Ambientais. 263 p. vol. 1, tomo 1.

RISSI, M.N.,2016. Efeito da época da queima na dinâmica de campo sujo de Cerrado. Rio Claro: Universidade Estadual Paulista, 141 p. PhD Thesis.

RIZZINI, C.T., 1997. Tratado de fitogeografia do Brasil: aspectos ecológicos, sociológicos e florísticos. Rio de Janeiro: Âmbito Cultural. $747 \mathrm{p}$.

SARMIENTO, G., 1984. The ecology of neotropical savannas. Cambridge: Harvard University. 235 p. http://dx.doi.org/10.4159/ harvard.9780674418554.

SIMON, M.F. and PENNINGTON, T., 2012. Evidence for adaptation to fire regimes in the Tropical Savannas of the Brazilian
Cerrado. International Journal of Plant Sciences, vol. 173, no. 6, pp. 711-723. http://dx.doi.org/10.1086/665973.

SIMON, M.F., GRETHER, R., DE QUEIROZ, L.P., SKEMA, C., PENNINGTON, R.T. and HUGHES, C.E., 2009. Recent assembly of the cerrado, a neotropical plant diversity hotspot, by in situ evolution of adaptations to fire. Proceedings of the National Academy of Sciences of the United States of America, vol. 106, no. 48, pp. 20359-20364. PMid:19918050. http://dx.doi. org/10.1073/pnas.0903410106.

SPECIESLINK, 2016 [viewed from 26 march 2016]. Available from: http://www.splink.org.br/

TANNUS, J.L.S., ASSIS, M.A. and MORELLATO, L.P.C., 2006. Fenologia reprodutiva em campo sujo e campo úmido numa área de cerrado no sudeste do Brasil, Itirapina-SP. Biota Neotropica, vol. 6, no. 3, pp. 1-27. http://dx.doi.org/10.1590/ S1676-06032006000300008.

TRABAUD, L. and CHANTERAC, B., 1985. The Influence of Fire on the Phenological Behaviour of Mediterranean Plant Species in Bas-Languedoc (Southern France). Vegetatio, vol. 60, no. 3, pp. 119-130. http://dx.doi.org/10.1007/BF00039927.

ZAR, J.H., 1999. Biostatistical analysis. Upper Saddle River: Prentice Hall. 662 p. 